\title{
A Critical Discourse Analysis of Dzawin's Stand Up Comedy Humor
}

\author{
Tias Sil Romansyah ${ }^{1}$, Didin Nuruddin Hidayat ${ }^{2}$, Alek $^{3}$, Dede Puji Setiono ${ }^{4}$ \\ \{tiassilromansyah@gmail.com ${ }^{1}$, didin.nuruddin@uinjkt.ac.id², alek@uinjkt.ac.id ${ }^{3}$, \\ dedepujisetiono@gmail.com ${ }^{4}$ \}
}

${ }^{1,2,3,4}$ UIN Syarif Hidayatullah Jakarta, Indonesia

\begin{abstract}
This research aims to describe the critical discourse analysis, the perception of comic and audience, and the content analysis of Dzawin's standup comedy humor discourse. Dzawin is the third winner of Indonesia Stand Up Comedy contest season 4 (SUCI 4) held by Kompas TV in 2016 and also the third winner of Maharaja Lawak Mega, one of the biggest comedy competitions in Malaysia in 2017. The qualitative descriptive method was employed in analyzing the data. The data were obtained from the video transcript of Dzawin accessed from YouTube. The data were then analyzed by using equivalent/ matching method (Padan Method). Additionally, the techniques used were the connect and compare distinguishing technique (teknik hubung banding membedakan/HBB Technique, hereafter), and connect and compare equation technique (teknik hubung banding menyamakan/HBS Technique, hereafter). The results show that Dzawin comedy heavily related to social-cultural construct discourse. Dzawin's humor discourse clearly shows negative and positive style where he humbly criticizes himself but simultaneously criticizes the society. Dzawin also appears to be a comic delivering the material not only to entertain but also to give some information to his audience. $\mathrm{He}$ somehow manages to deliver a moral value on his material of humor discourse. Finally, Dzawin's humor discourse exposes social problems occurred in Indonesia and attempts to persuade people to fix bad behavior.
\end{abstract}

Keywords - Critical discourse analysis, humor discourse, stand-up comedy

\section{Introduction}

Humor is something that can make people laugh. Humor can be found around us; it can be found from texts and talks. Humor also can be found from social phenomena with analyzing, compiling, and then delivering it through speech and action. Humor is subjective because it depends on the context [1]. One feels that kind of humor but the other one does not feel the same. Humor is something that can tickle others to laugh by using physical/ body (slapstick) or utterances [2]. Humor also comes in many forms. It is found all over the world in ordinary conversation, novels, plays, TV shows, and movies. A humor performance could be made by group of people by creating a skit or a play or by a single person delivering the comedy through its actions only such as Charlie Chaplin's pantomime or by delivering verbal narration such as stand-up comedy show. In other words, humor is an omnipresent phenomenon. By virtue of modern technology, humor in many formats, including a stand-up comedy is now available to the masses. Websites such as Netflix or YouTube offer large amounts of stand-up comedy from a variety of comedians twenty-four hours a day.

The term stand-up comedy usually refers to a humor show performed by a comedian in front of an audience. The contents of performances can vary greatly from one comedian to 
another. For instance, one comedian might be known for political satire whereas another comedian may use seemingly vulgar or indecent language. Stand-up comedy is a style of comedy that has its roots in American culture, and it has quickly become a significant part of entertainment and popular culture. The people who do the stand-up comedy called comic.

Stand-up comedy is a natural rhetorical discourse; it is not only to entertain, but also to persuade [3]. In the Indonesian context, stand-up comedy becomes popular since 2011 when Kompas TV, a private media broadcasting company, organized the very first time televised stand-up comedy competition called Stand-Up Comedy of Indonesia (SUCI).

Stand-up comedy is part of jokes, but there is something different or uniqueness from how to deliver it. The comic communication style in stand-up comedy is not just talk like a comedian and conventional skits or plays' joke style, but also there is critic and satire that is packed with more humorous style. In addition, besides entertaining, there is an aspiration that comes from the comic to against the phenomena that occur nowadays and it also can be new knowledge for audience who watch it. Thus, stand-up comedy could also be regarded as a form of comedy art performance. Usually, a comedian stands up in front of the audience and speaks directly to them with certain message they intend to deliver. The message could be about social or any issues and all are wrapped in a humorous verbal language.

Language in humor especially in stand-up comedy which rely on verbal communication plays a central role. Humorous utterance constitutes a significant portion of stand-up comedy performance and stands as major and universal functions of communication means along with its function to convey information funnily. Despite the difficulties to construct theory explaining how language could trigger humor, linguistic approach called discourse analysis attempt to elaborate the matters. Discourse analysis is used widely in a variety of disciplines and there are many different approaches that comprise discourse analysis. In Discourse analysis, language is not only analyzed by describing from the language aspect but also relating to the context. The context means that the language is used for certain purposes and practices. There are four principles of critical discourse analysis: social and political issues, power relations, social relations, and ideologies.

Language used in humor especially stand-up comedy usually is a daily based vocabulary language. Although language in humor seems looks all similar, linguistic evidence shows that humorous language differs from other types of language [4] [5]. However, there is no current research available to support the current theories. What is more, the studies conducted by [4] and [5] solely researched humorous language as found in written texts and not found in other types of humorous language, such as stand-up comedy. Neither seem particularly interested in the workings of the language of stand-up comedy. Furthermore, there are no current studies available where the theories of [4] and [5] tested on the language of stand-up comedy to see whether this type of humorous language adheres to the same theories as written humorous language. Thus, this research trying to fill the gap by focuses on describing the critical discourse analysis, the perception of comic and audience, and the content analysis of stand-up comedian. The standup comedian chosen as the subject in this study is Dzawin as he is one of the prominent stand-up comedian figures in Indonesia. Dzawin is the third winner of Indonesia Stand-Up Comedy season 4 (SUCI 4) held by Kompas TV in 2014 and also the third winner of Maharaja Lawak Mega one of the biggest comedy competitions in Malaysia in 2017. In addition, the researchers were interested to conduct the research about Dzawin's material as the subject of the research because it seems to indicate that some previous related studies did not concern on stand-up comedy humor in English. Hence, it is necessary to conduct the research in terms of stand-up comedy humor. 
To guide this research, the following questions are imposed: 1) What are the characteristics of critical discourse analysis in Dzawin's stand-up comedy humor? 2) How is the perception of comic and audience in interpreting the critical side of social reality of Dzawin's humor discourse? 3) What is the classification of discourse based on the content in Dzawin's humor discourse?

\section{Literature Review}

Humor such as stand-up comedy has long been gaining considerable attention form researchers. Linguists such as [4] and [5] for instance, have proposed various linguistic humor theories, which describe figurative language features of humorous language found in written texts such as novels and spoken forms such as plays. According to Attardo, humor is an "allencompassing category, covering any event or object that elicits laughter, amuses, or is felt to be funny" (2010, p. 4). He divides humor theories into three categories: essentialist, teleological, and substantialist. The first two categories are the study of 'sociolinguistic approaches [4]. He further explains that it is widely recognized that humor research is an interdisciplinary field and that it started with the great philosophers Plato and Aristotle. In those times humor was seen as a 'mixed feeling of the soul' and as a 'stimulation of the soul'.

Similar to Attardo, Nash finds the question as to what makes language particularly funny a difficult one. He even suggests that there is no clear answer to that question. He does mention that some 'items' of language (words, phrases, etc.) are 'intrinsically humorous', but that the search for the intrinsically funny is a 'forlorn enterprise'. [5] explains that it is safer to assume that the "properties of humorous expression are defined extrinsically" so that words and phrases seem funny because of their "contextual linkages and semantic relationships" (p. 127).

In a specific form delivery of humor such as in stand-up comedy where the trigger of the laughing from the audience is mainly caused by verbal one way communication, the creation of humor in stand-up comedy is seen as a combination of various linguistic features of joke telling such as wordplay and punning, hyperbole, repetitions, timing, and paralinguistic choices. In addition, the comedians develop a specific stage persona and create their own style of performing. Spontaneity and flexibility are shown to be two of the most important characteristics that a stand-up comedian must possess in order to give a successful performance.

Reference [6] additionally explains four humor styles that correspond to the inclusive and exclusive humor that the might come from standup comedy context. They state that in literature, humor has 'two positive styles (affiliative and self-enhancing)' and two 'negative (aggressive and self-defeating)' styles. These humor styles represent the ways that individuals use in order to cope with others, relationships and stress in everyday life. They define selfenhancing humor as encompassing personal aspects of humor and referring to a humor style that individuals use to cope with stress, change their perspective about problems or minimizing negative emotions. The other positive humor style, affiliative humor, is described as a humor style in which individuals focus on others while not ignoring their own needs, it is used in a "respectful manner (toward oneself and others)" and is often used to improve relationships and interactions among people.

The first form of negative humor is aggressive humor, a style of humor in which individuals use humor in a socially inappropriate, detrimental way in the expense other in order to satisfy their own needs about their superiority and pleasure. The last type of humor they describe is self-defeating humor or ridicule humor. This is a humor style in which individuals do not regard their own needs and constantly bash and denigrate themselves in a 
humorous way' in order to deny their true feelings and to pretend to be happy in order to make 'others also fall into this category.

As stand-up comedy is not merely about delivering humor but have a message to deliver as well, analyzing the language used in this type of humor performance requires a discourse. Reference [7] reports that studies of discourse analysis which could be employed to investigate any utterances can be classified along two different theoretical dimensions. The first dimension deals with the significance of text versus context. The second dimension is concerned with the extent of studies that focus on power relations versus studies that focus more on processes that constitute social reality. Reference [7] identify four major perspectives that are used in empirical studies from these two axes: social linguistic analysis, interpretive structuralism, critical discourse analysis and critical linguistic analysis.

Critical discourse analysis can be used to analyze how discourses shape stereotypes and social structures. Reference [8] posits that discourse analysis and its relation to power should be an analysis of power effects. Similarly, Reference [9] asserted that critical discourse analysis is a type of discourse analytic research that primarily studies ways in which abuse, dominance, and social power inequalities are enforced, reproduced, and opposed by texts and speech in social and political context.

Additionally, the purpose of critical discourse analysis is to express some of the hidden and invisible values, positions, and perspectives and critical discourse analysis also starts with the assumption that language use is always social and that discourse both reflects and constructs the social word [10]. Discourse analysis uses language in the text to be analyzed, but the language analyzed is different from the study of language in terms of traditional linguistics.

Some studies have been conducted regarding to this humor and discourse analysis issues. Reference [11], for instance, has conducted the study of critical discourse analysis of Abdurrahim Arsyad a comic from stand-up comedy season 4 (SUCI 4) on Kompas TV. In her study, she mentions that there were three aspects to be analyzed; 1) the characteristic of critical discourse analysis in Abdur's humor discourse; 2) the perception of comic and audience, and the last was 3) the classification of discourse based on the content of Abdur's humor discourse. Reference [11] reveals that Abdur's stand-up comedy is all about the use of the political power. Politicians are more concerned with the problems of elite politics and party members than the issue of public interest. Abdur also criticized the government about discrimination of eastern people and disappointment with the government in eastern people who lacked the government's attention.

In addition, in the humor discourse delivered by Abdur as [11] argues also criticized education, infrastructure, social needs, information technology, social inequality issues, Indonesians who do not care about their art and culture, low performance in sports, and lack of government assistance to social health in remote villages. The context as a comic that cannot hinder from Abdur's life background makes people express social problems. Abdur's perception and audience is that Abdur's humorous discourse has something that can arouse audience interest, not only for entertainment but also for messages that make them pay more attention to the environment around them.

\section{Methods}

This research discusses about critical discourse analysis of Dzawin's stand-up comedy humor. The method used in this research was qualitative descriptive. The data were collected from video of Dzawin on YouTube. The researchers transcribed the transcript of the video in 
order to make it easy to interpret the data. After transcribing and selecting the data, it was necessary to examine them thoroughly in order to identify categories for the analysis. The study applied content analysis in order to devise a cohesive description of the phenomenon in question. The data were analyzed by using equivalent/matching method (Padan Method) proposed by [12]. The equivalent used is referential equivalent, namely the determinant of the reality designated by language. The data analysis techniques used in this research is a form change technique (teknik ubah wujud). The data were in the form of oral discourse, and then were changed into written discourse. The data were then later paraphrased in order to clarify the discourse. Additionally, the techniques employed in this study are the connect and compare distinguishing technique (teknik hubung banding membedakan/HBB Technique) and the connect and compare equation technique (teknik hubung banding menyamakan/HBS Technique).

\section{Findings}

\section{A. The characteristic of discourse analysis in Dzawin's standup comedy humor}

\section{Action}

The discourse that shows action in Dzawin's stand-up comedy humor discourse can be seen from the following utterance.

“... I hope you can understand my English because sometimes I don't really even understand what I'm saying. I write down all my materials from Indonesia into the English and memorize it even the word I write down all my materials and memorize it and memorize it."

Based on his utterances above, it can be seen that he realized that he had to speak English in delivering his comedy humor discourse because he was in Malaysia and the audience was Malaysians in which should be considered and treated as international audience in which they do not share the same mother tongue with Dzawin.

Context

The discourse that shows context in Dzawin's stand-up comedy humor discourse can be seen from the following quote.

“...I'm Indonesian. I come from Indonesia, so maybe you never see a funny Indonesian in Malaysia"

Based on his utterance above, it can be seen that there is a different humor between Indonesia and Malaysia. Something funny in Indonesia may not be funny in Malaysia because of the different contexts between the two.

Another discourse that shows context in Dzawin's stand-up comedy humor discourse can be seen from the following quote.

“...we usually come to Malaysia not to be a funny Indonesian but to be a hard-working people" 
Based on his other utterance, it can be concluded that Indonesian people who come to Malaysia are not normally to be a comedian, but they prefer to be a hard worker, for instance Indonesian labors (TKI), businesspersons, entrepreneurs, or other.

\section{B. The perception of comic and audience in interpreting the critical side of social reality of Dzawin's humor discourse}

Perception of comic or Dzawin in interpreting the critical side of social reality of Dzawin's humor discourse

The gist of some discourse material of Dzawin is about social-culture of Indonesian. $\mathrm{He}$ seems to indicate that Indonesian people when going to the mosque they will lose their slippers or shoes. It means that the Indonesians are still lack of good manner.

Perception of audience or the researcher in interpreting the critical side of social reality of Dzawin's humor discourse

We are as audience obtain a lot of information from Dzawin's humor discourse material. It seems not only to entertain but also to persuade us to be better people. Through stand-up comedy, all his materials consisted of moral value. For instance, as an Indonesian, he or she realizes that stealing is a bad attitude. Having said that, in Islam religion, stealing is forbidden and people who do it will get punishment ( $\sin )$.

\section{The classification of discourse based on the content in Dzawin's humor discourse}

Social-cultural Discourse

The discourse that shows social discourse in Dzawin's stand-up comedy humor discourse can be seen from the following quote.

“...I always go to the mosque, I always lose my slipper, and I always go to the mosque, I always lose my shoes".

Based on his utterance above, it can be seen that some of Indonesian have bad attitude, for instance taking other people slipper or shoes. As we know, stealing is bad attitude and people who do it will get sin in Islam.

\section{Discussion}

Dzawin stand-up comedy seems to combine both positive and negative styles of humor where he humbly attacked himself and as well criticize the society surrounding him. In humor theory, he appears to employ self-defeating style or "ridicule" method. Ridicule is features of the joke telling techniques that display impoliteness and aggressiveness. The ensuing laughter on the recipients' part stresses their agreement and therefore strengthens the intention of excluding a certain group. Reference [4] further distinguishes various types of ridicule and also presents "private ridicule", "shared-ridicule" and "self-ridicule". Private ridicule is distinguished by the fact that "the butt of the derision is absent and unlikely to hear of the wit, or dead and buried". This provides an opportunity to express overt hostility towards authority 
and can therefore even cause a feeling of solidarity among like-minded people against the person who is the butt of the humor.

Shared ridicule is being used when the jokers deride themselves and their audience at the same time. In this study, it is found that Dzawin use shared ridicule when he addressed shared Muslim behavior that he sees is not appropriate. By ridiculing someone or something, the speaker wants to express hostility and superiority by criticizing the behavior of a specific person or group in question. In stand-up comedy, people principally encounter private and shared ridicule, the aim of which is to focus on a specific person or group by presenting them as ridiculous and silly.

As Dzawin delivered in his comedy, there are as well many joke topics that could be shown on a humor performance. Jokes can be based on, for instance, politics, entertainment, ethnic jokes, self-disparaging humor or even taboo ones, exploiting topics that are not often discussed openly or in a joking manner in society [13].

It might be easy to assume stand-up comedy to be purely a collection of jokes. Many of the jokes in stand-up comedy performances are dependent on the context that they are told in. For instance, it can be observed that comedians often use a particular broader theme for a large number of jokes such as Dzawin jokes about people and mosque. Thus, removing these jokes out of the context of the performance may result in different response from the audience.

The other features that separates Dzawin from the crowd is that he not only tells humorous stories for entertainment purposes, but that these stories actually move people. From the way Dzawin addresses his audience, one notices that he is very critical of many aspects of the Indonesia and its inhabitants. This is another characteristic of humor: it can educate as well as entertain. In his stand-up acts Dzawin also applies some political satire. Since satire is a genre of comedy that is "directed at ridiculing human foibles and vices" in order to "expose and censure such faults" ( [14], p. 21), political satire specializes in exposing these faults in the realm of politics. Political satire forms a part of Dzawin's shows, mostly when he discusses social issues.

According to the analysis above, Dzawin is a comic that delivers the material not only to entertain but also to give some information. He somehow managed to deliver a moral value on his material of humor discourse. In the research as the context as comic, Dzawin from his humor discourse tried to expose a social problem happened to Indonesian and persuade people to fix that bad attitude. Furthermore, in the audience's point of view, the overall materials that Dzawin explained have relatable daily based comedy. That way, he was able to indirectly ask the audience to have a better attitude. All things considered, based on Dzawin performance in terms of characteristic of discourse analysis, perception of audiences, and classification of context on the content have very meaningful material to ponder.

\section{Conclusion}

Stand-up comedy is one of the media to expose a social phenomenon through humor discourse. In this research subject, the vision and mission of Dzawin in delivering material jokes in his standup comedy appears to fulfil that role where his humor intends to educate the society and is not just solely for entertainment purpose. On the other side, this study showed that figurative language does add to the persuasiveness of Dzawin's message for it is the function of rhetorical devices to persuade an audience. Since Dzawin uses many of such devices in his utterances, their persuasiveness is thus enhanced. Dzawin humor discourse clearly show negative and positive style where he humbly criticizes himself but at the same time, he also criticizes the society. He seems to be doing it on purpose to create humorous 
instances because when there is something incongruous, stimulating surprise, or a sense of superiority in the laughter, the audience are likely easier to receive the message of the jokes. One could thus argue that incongruity-based jokes, as Dzawin did, make up the bulk of jokes. It might play a crucial role in humor as a social phenomenon, as most humor is based on violations of socially or culturally agreed norms.

\section{References}

[1] A. Wortley and E. Dotson, "Stand up comics: Instructional humor and student engagement," Journal of Instructional Research, vol. 5, pp. 13-18, 2016.

[2] Darmansyah, Strategi pembelajaran menyenangkan dengan ilmu humor, Jakarta: Bumi Aksara, 2012.

[3] A. Greenbaum, "Stand-up comedy as rhetorical argument: An investigation of comic culture," Humor International Journal of Humor Research, vol. 12, no. 1, pp. 33-46, 1999.

[4] S. Attardo, "De Gruyter Mouton," January 2010. [Online]. Available: https://www.degruyter.com/view/product/13075. [Accessed 13 May 2019].

[5] W. Nash, The language of humor, New York: Longman, 1985.

[6] Ö. Karakuş, F. Z. Ercan and A. Tekgöz, "The relationship between types of humor and perceived social support among adolescents.," Procedia - Social and Behavioral Sciences, vol. 152, p. 1194-1200, 2014.

[7] M. Jørgensen and L. Phillips, Discourse Analysis., London: Thousand Oaks, 2002.

[8] J. Blommaert, Discourse: A critical introduction, New York: Cambridge University Press, 2005.

[9] A. D. Darweesh and N. M. Abdullah, "A Critical Discourse Analysis of Donald Trump's sexist ideology," Journal of Education and Practice, vol. 7, no. 30, p. 87-95, 2016.

[10] B. Paltridge, Discourse Analysis: An introduction, London: Bloomsbury Publishing, 2007.

[11] D. A. Wulandari, "Analisis wacana kritis dalam wacana humor Abdurrahim Arsyad Stand Up Comedy 4 (Suci 4) di Kompas TV," Universitas Muhammadiyah Surakarta, Surakarta, 2016.

[12] Sudaryanto, Metode dan aneka teknik analisis bahasa, Yogyakarta: Duta Wacana University Press, 1993.

[13] M. Toikka and M. Vento, Ala naurattaa! stand up -komedian käsikirja, Helsinki: Cosmoprint, 2000.

[14] S. Hamilton, Essential literary terms: A brief Norton Guide with exercises, New York: W.W. Norton \& Company, Inc., 2007. 